\title{
ARE INVESTMENT AND FINANCING DECISIONS REALLY INDEPENDENT? EVIDENCE FROM CHEMICAL SECTOR OF PAKISTAN
}

\author{
ZEESHAN MUKHTAR \\ SHUJAHAT HAIDER HASHMI \\ Capital University of Science and Technology, Islamabad, Pakistan \\ MUHAMMAD ASAD \\ Mirpur University of Science and Technology, Mirpur, Pakistan
}

\begin{abstract}
The study aimed at exploring the impact of financial leverage on investment decision to identify the contradictions in theories like Fisher Separation Theorem (1930), MMIrrelevance Theory (1958), and Theory of Investment (1969). A sample of 30 chemical sector companies was taken. Panel regression was applied to check the impact of financial leverage, liquidity, cash flows, profitability, firm size and growth on firm investment decision. Results revealed that financial leverage had a significant negative effect on investment decision, while liquidity, profitability, cash flows and firm size had a positive significant effect on firm investment. The findings imply that investment decision should not be treated separately by finance managers and investors as excessive level of leverage has a drastic effect on investment opportunities.
\end{abstract}

\section{INTRODUCTION}

In today's volatile and uncertain environment, investment decision has a strategic importance for the companies as it paves the way for their future growth and long-term success (Kannadhasan \& Aramvalarthan, 2011). Our corporate sector has a key role in economic growth, as it brings new avenues for investment opportunities. Challenges of global competition exert pressure upon companies to invest heavily in new technologies, infrastructure, product development, product management and meet development needs. However, investment requires acquiring and utilization of funds from appropriate sources. Therefore, companies either use internal funds or go for external financing by issuing shares or debt. Efficient utilization of funds has an integral role for managing growth and enhancing firm value. In this regard, leverage or debt is now considered inevitable for both firms and countries for maximizing return especially in developing countries (Kannadhasan, 2014). Nevertheless, it requires understanding of various investment and capital structure theories to decide upon appropriate mix of debt and equity.

It has been a long debate whether investment and financing decisions are independent or not. For example, Irving Fisher postulated the famous Fisher Separation Theorem in 1930; he was of the view that investment value does not rely upon choice of debt or equity. Therefore, the shareholders should motivate and influence the managers to make right choice of investment options to maximize net present value of projects. Based on this notion, Modigliani and Miller (1958) presented Capital Structure Irrelevance Theory; they argued that value of firm remains unchanged whatever mix of debt or equity is used. However, Modigliani and Miller in 1963 refined their irrelevance theory and argued that corporate taxes may affect firm value by providing tax shield on interest payments in imperfect market. James (1969) gave the Theory of Investment that declares that investment and financing are separate decisions. However, Trade-off Theory of capital structure holds that leverage has both advantages and disadvantages. Debt provides benefit of tax shield to a certain optimal level, and its excessive use leads to higher cost of bankruptcy. In business, companies use leverage and try to create wealth for shareholders, but if it does not, interest cost and the credit risk of non-payment destroy value for shareholders. The relationship between funding and investment has been the central issue in the study of corporate finance.

Empirical research shows that there is a strong association between leverage and investment decision as opposed to above-mentioned theories. Several studies have documented negative relationship between leverage and firm investment decision (e.g., Aivazian et al., 2005; Odit \& Chittoo, 2008; Singhania \& Seth; 2010; Sajid et al., 2015). These findings indicate that there is a problem in the applicability of the above stated theories. So, it is necessary to explore whether the contradiction between 
these theories and empirical literature is acceptable or not. The main supposition of MM Irrelevance Theory, Fisher Separation Theorem and Theory of Investment is that all such decisions are taken in perfect capital market. However, in reality, this notion of fully efficient market does not hold true in contemporary business world, especially emerging economies like Pakistan. Therefore, it requires an empirical investigation to test such theories in our financial environment.

This study examines the impact of financial leverage on investment decision in chemical and pharmaceutical sectors. These sectors are closely related to each other and are a growing part of the economy. Other variables such as liquidity, profitability, cash flows, firm size and growth, that may have a substantial influence on the relation between investment and financing decision have been controlled as these factors are also considered by the companies while making investment decision. For example, availability of cash flows have a positive effect on increasing the investment level. Similarly, profitable firms have more funds to avail investment opportunities. The findings of our research are applicable for managers, shareholders, other investors, financial institutions and regulatory authorities, as excessive and opportunistic use of leverage may negatively affect investment decision, and may have adverse effect on long-term growth and survival of the company.

The remaining paper is organized as follows. In the second section, empirical literature has been discussed pertaining to determinants of investments. The third section elaborates the methodology, research design and analytical approach of this research. Results have been elaborated in the fourth section. Lastly, conclusion has been drawn and policy recommendations have been given.

\section{REVIEW OF LITERATURE}

The capital structure is determined by the benefits of swapping debt to the cost of debt (Harris \& Raviv, 1991). Modigliani and Miller (1958) claimed that the investment policy of a company should be based solely on the factors that would increase profitability, cash flow, or net worth of a company. Many pragmatic literature challenged Modigliani and Miller irrelevance theorem. The irrelevance proposition by Modigliani and Miller is valid only if the underlying assumptions of perfect market analysis are met. For example, Stulz (1990) argued that debt payments could reduce free cash flows, thereby reducing funds available for investment in profitable opportunities. The dealings among managers, shareholders and debt holders could generate conflict because of agency problems, which might lead to underinvestment or overinvestment incentives.
Myers (1977) investigated the difficulties that businesses can face for obtaining financing to carry on positive net present value (NPV) of projects, if they are highly leveraged. Therefore, leverage may lead to liquidity problems and could affect the ability of the company to maintain growth. In this situation, the debt overhung problem reduces firm investment. However, Fama and French (1988) disagreed with this notion, arguing that more profitable firms tend to have lower levels of debt.

Leverage may create both underinvestment and overinvestment problem (Myers, 1977; Odit \& Chittoo, 2008). Underinvestment theory states that high leverage has a negative effect on investment as high-levered firms face financial difficulty to maintain growth by carrying on positive NPV projects than low-levered firms. Therefore, such firms use their earnings and liquid funds to service debt, and excessive leverage put unnecessary pressure to curtail investment. Thus, underinvestment is based on liquidity theory that leverage may lead to technical insolvency problem.

Another explanation for negative relation between leverage and investment is based on overinvestment theory. Overinvestment theory revolves around agency problem that extra debt create conflict between managers, shareholders and lenders (Myers \& Majluf, 1984). Managers may go beyond limit of positive NPV projects, and may invest the funds in poor projects leading to asset substitution problem. Therefore, leverage acts as controlling mechanism to reduce unnecessary investment. Empirical evidence is also available about the possible effect of leverage on investment.

\section{Financial Leverage and Firm Investment}

Several studies have evidenced negative relation between financial leverage and investment, for example, McConnell (1995) and Singhania and Seth (2010) found the negative effect of financial leverage on investment. Harris and Raviv (1990) found the same results. They argued that managers and shareholders cannot agree on business decisions. Managers tend to prefer the company to continue operations even if the liquidation is preferred. Moreover, funds generated from leverage could be used for making working capital investment (Amidu, 2007). However, Aivazian et al. (2005) argued that financial leverage does not always lead to underinvestment problem; managers could make overinvestment to meet their ambitious plans and increase their short-term gains. Franklin and Mouthusamy (2011) found significant positive relationship between debt and investment for high growth firms. Therefore, we expect either positive or negative relation between leverage and investment. 
Hypothesis 1. There is significant effect of leverage on firm's investment.

\section{Profitability and Firm Investment}

Other factors that could have potential effect on firm investment were also taken. Profitability is one of those important factors that could significantly affect firm investment. For example, Myers and Majluf (1984) held that successful companies do not have an over-reliance on external financing because they rely on internal reserves. Therefore, companies use more internal funds for making investment. Lang, Ofek, and Stulz (1996) argued that leverage reduces profitability; therefore, they do not carry positive NPV projects because more debt increases opportunity cost of borrowing funds. Stulz (1990) found positive relation between profitability and firm's investment. Singhania and Seth (2010) also reported positive relation between profitability of company and leverage used by firms. Therefore, we expect that profitable companies are in a better position to make more investment as they prefer internal funds according to Pecking Order theory.

\section{Hypothesis 2. There is a significant positive} effect of profitability on firm's investment.

\section{Firm Size and Firm Investment}

Firm size is the second factor that can have a positive effect on firm's investment. Larger firms have more resources according to Resource-Based View; these firms can easily obtain funds from the financial market (Myers \& Turnbull, 1977). Abir (2010) found a positive relationship between firm size and leverage ratio; it implies that larger firms are in better position to take more debt. Larger firms also make more production and achieve economies of scale, these firms obtain higher returns by making more investment (Lawrence, Diewert, \& Fox, 2004). Ju and Ou-Yang (2006) documented positive effect of firm's size on firm's investment. Similar results were also supported by Amidu (2007). Based on this discussion, positive relation is expected between firm's size and investment.

\section{Hypothesis 3. There is a significant positive} effect of firm's size on firm's investment.

\section{Cash Flows and Firm Investment}

Cash flows also play an important role in firm's investment. Availability of cash flows provide more opportunities for investment. Investment is more sensitive to cash flows. Higher level of cash flows provides more opportunities for firms to make investment. For instance, Joseph (2002) explained that cash flows have a positive relation with investment in UK. Franklin and Mouthsamy (2011) suggested that cash flows play a positive role in identifying investment decisions. Hyde (2007) also concluded that sudden change in the value of cash flows could affect the firm's value and investment in the eyes of stake holders.

\section{Hypothesis 4. There is a significant positive effect of cash flows on firm's investment.}

\section{Liquidity and Firm's Investment}

Liquidity also affects firm's investment. Singhania and Seth (2010) investigated a positive correlation between liquidity of the firm and firm's investment. Higher liquidity makes firms attractive for investors and they make more investment. Similarly, Guney, Ozkan. A, and Ozkan. N (2007) also found positive relation between liquidity and firm investment.On the other hand, Harris and Raviv (1990) found negative relation between liquidity and financial leverage. It means that lower liquidity cause firms to involve in more debt for making investment in the company. Sajid et al. (2015) evidenced a positive effect of liquidity, cash flows and profitability on firm's investment. Based on these results, we expect positive effect of liquidity on firm's investment.

\section{Hypothesis 5. There is a significant positive effect of liquidity on firm investment.}

\section{Growth and Firm Investment}

Tobin's Q is usually taken as proxy for firm's growth. High-growth firms tend to reduce information asymmetry and provide better aspects for obtaining funds as compared to low-growth firms. Low-growth firms are considered to have lower cash flows and availability of funds. These firms having low Q find financial constraint in obtaining funds for investment (Aivazian et al., 2005; McConnell \& Servaes, 1990). Amidu (2007) and Singhania and Seth (2010) determined the negative affect on firm's investment. Odit and Chittoo (2008) and Jiming, Chengqin, and Zhaohua (2010) also found a negative effect of firm's growth on firm's investment.

\section{Hypothesis 5. There is a significant negative effect of firm's growth on firm's investment.}

Based on the literature review, we can say that there are a few studies which explain the application of The Separation Theorem of Fisher (1930) and Irrelevance 
Theory (1958) in our corporate sector. Most of the studies have been conducted to check the impact of financial leverage on profitability, dividend policy and assets pricing (El-Wahid \& Su'ad Husnan, 2011;Asif, Rasool, \& Kamal, 2011).

\section{METHODOLOGY}

The research has been done to check the effect of financial leverage on investment decision of 30 companies taken from Chemical sector listed in Pakistani stock market. There are two types of companies in this sector; chemical and pharmaceutical. Data has been taken from their annual reports, stock exchange and Securities and Exchange Commission of Pakistan from 2001 to 2013. The following econometric model has been applied and tailored from the study of Aivazin, Ge and Qiu (2005).

$\Delta \mathrm{K}_{\mathrm{it}}=\beta_{\mathrm{o}}+\beta_{1} \mathrm{LEV}_{\mathrm{i}, \mathrm{t}-1}+\beta_{2} \mathrm{CF}_{\mathrm{i}, \mathrm{t}-1}+\beta_{3} \mathrm{LIQ}_{\mathrm{i}, \mathrm{t}-1}+\beta_{4} \mathrm{PRF}_{\mathrm{i}, \mathrm{t}-1}+$ $\beta_{5} \mathrm{SIZ}_{\mathrm{i}, \mathrm{t}-1}+\beta_{6} \mathrm{GTH}_{\mathrm{i}, \mathrm{t}-1}+\mu_{\mathrm{i}, \mathrm{t}-1}$

The variables, their respective proxies and expected relations are described as follows:-

$\Delta \mathrm{K}_{\mathrm{it}}$ represents change in the value of net fixed assets of the firm $\mathrm{i}$ during the time $\mathrm{t}, \mathrm{CF}_{\mathrm{i}, \mathrm{t}-1}$ cash flows of firm $\mathrm{i}$ at time $\mathrm{t}-1, \mathrm{LEV}_{\mathrm{i}, \mathrm{t}-1}$ leverage of firm $\mathrm{i}$ at time $\mathrm{t}-1, \mathrm{LIQ}_{\mathrm{i}, \mathrm{t}-\mathrm{1}}$ liquidity of firm $i$ at time $t, \mathrm{PRF}_{\mathrm{i}, \mathrm{t}-1}$ profitability of firm $\mathrm{i}$ at time t-1, SIZ ${ }_{i, t-1}$ size of firm $i$ at time $\mathrm{t}-1, \mathrm{GTH}_{\mathrm{i}, \mathrm{t}-1}$ it is Tobin's $Q$ of firm $i$ at time $t-1, \mu_{i, t-1}$ error term of firm $i$ at time $\mathrm{t}-1$.

The leverage has been measured using the ratio of total liabilities to book value of assets (Lang et al., 1996). The negative sign is expected between leverage and investment (Aviazian et al., 2005; Odit \& Chittoo, 2008). Liquidity is defined as current assets to current liabilities. The higher the liquidity, the higher would be the amount spent on investment; positive relation is expected between liquidity and firm investment (Franklin \& Mouthsamy, 2011). Profitability has been measured using return on assets ratio. Profitable firms have more funds for making investment and therefore positive relation is expected (Wiwattanakantang, 1999; Singhania \& Seth, 2010). Growth has been measured using the formula of Tobin's Q by Wiles (1994) as market value of equity + liabilities divided by book value of assets. The negative relation is expected between Tobin's Q and firm investment (Jiming et al., 2010). Cash flows are natural logarithm of net profit before tax plus depreciation and extraordinary items. Higher level of cash flows induces more investment by firms (Joseph, 2002; Franklin \& Mouthsamy, 2011). Size is taken as natural logarithm of net sales. Marsh (1982) found that larger companies make more investment.

Panel regression has been applied to analyze the effect of leverage on firm's investment. Firstly common and fixed effect models have been compared on the basis of Redundant F Test (LM Test). Since the F-value was found significant $(F-v a l u e=9.96 ; p<0.01)$, so fixed effect model was selected. Later on, Hausman test was applied to compare the results of fixed and random effect model. Our final model was fixed effect model since chi-square value of Hausman test was found significant (chi-square value $=57.3 ; \mathrm{p}<0.01$ ). We also checked the problem of autocorrelation and heteroskedasticity, and found insignificant results.

\section{RESULTS AND DISCUSSION}

The results are given in the form of descriptive statistics, correlation matrix and regression table. Table 1 reports descriptive measures of all variables. For example, the average value of leverage of companies in chemical sector is 31 percent approximately. An empirical research about international comparison of capital structures of firms concludes that developing countries have a relatively high leverage ratio (Odit \& Chittoo, 2008).

TABLE 1

Descriptive Statistics

\begin{tabular}{lllll}
\hline VARIABLES & Mean & Max & Min & SD \\
\hline Investment & 6.061 & 10.416 & 2.493 & 1.817 \\
Leverage & 0.318 & 3.833 & 0.001 & 0.340 \\
Liquidity & 8.180 & 83.475 & 0.023 & 52.192 \\
Profitability & -0.038 & 0.881 & -19.228 & 1.369 \\
Cash flows & 5.297 & 14.336 & -1.204 & 2.099 \\
Firm Size & 7.059 & 11.387 & 1.322 & 2.090 \\
Growth & 3.235 & 61.706 & 0.036 & 7.874 \\
\hline
\end{tabular}

$S D=$ Standard Deviation

The leverage ratio in Pakistan is less than the medium value of developing countries and above the medium value for developed countries. On the average, the companies in this sector are showing losses. Liquidity position of such companies seems to be very high.

Table 2 depicts significant negative relation between financial leverage and firm investment $(p<0.05)$. These results are in accordance with Odit and Chittoo (2008); it implies that higher level of debt may lead to decrease in investment. On the other hand, positive association has been found between liquidity and investment $(\mathrm{p}<0.05)$; the higher liquidity ratio ensures availability of funds for firm's investment as lack of liquid assets may create problem of technical insolvency. 
TABLE 2

Correlation Matrix

\begin{tabular}{|c|c|c|c|c|c|c|c|}
\hline & INV & LEV & LIQ & PRF & CF & SIZ & GTH \\
\hline INV & 1 & & & & & & \\
\hline LEV & $-0.140 *$ & 1 & & & & & \\
\hline LIQ & $0.048^{*}$ & -0.110 & 1 & & & & \\
\hline PRF & $0.320 * *$ & -0.040 & 0.004 & 1 & & & \\
\hline $\mathrm{CF}$ & $0.360 * *$ & -0.010 & 0.007 & $0.620^{*}$ & 1 & & \\
\hline SIZ & $0.825 * *$ & -0.010 & -0.05 & $-0.388^{*}$ & $-0.429 * *$ & 1 & \\
\hline GTH & -0.070 & -0.110 & -0.024 & 0.026 & 0.009 & -0.010 & 1 \\
\hline
\end{tabular}

Therefore, firms in chemical sector wants to maintain their liquidity position to carry on investments. Moreover, cash flows, profitability and firm size have a positive significant relation with firm investment ( $p$ $<0.01)$. Cash flows also play a vital role to determine the growth opportunities. Larger firms also make more investment as compared to smaller firms.

TABLE 3

Fixed Effect Model

\begin{tabular}{lllll}
\hline Variable & Coefficient & SE & t-Stat & Prob. \\
\hline Constant & 3.518 & 0.551 & 6.391 & 0.000 \\
Leverage & -0.492 & 0.166 & -2.960 & 0.003 \\
Liquidity & 0.003 & 0.001 & 2.608 & 0.005 \\
Profitability & 1.289 & 0.360 & 3.583 & 0.000 \\
Cash flows & 0.177 & 0.057 & 3.108 & 0.002 \\
Firm size & 0.275 & 0.089 & 3.077 & 0.002 \\
Growth & -0.008 & 0.009 & -0.927 & 0.355 \\
R-Squared & 0.846 & & & \\
Adjusted & 0.823 & & & \\
R-Squared & & & & \\
F-Statistic & 63.883 & & & \\
Prob. & 0.000 & & & \\
(F-Statistic) & & & & \\
Hausman Test & $57.3 * * *$ & & & \\
& $(0.000)$ & & & \\
\hline
\end{tabular}

Table 3 reports the results of panel regression in case of fixed effect model, that is, our final model based on the significant value of Redundant $F$ test and Hausman test as reported in methodology section. The model explains 84.6 percent variation in dependent variable. It has a very good prediction and explanatory power. Moreover, F-value is significant which implies that model is overall a good fit and can be used for generalization. The leverage has negative significant effect $(\beta=-0.492 ; p<0.01)$ on investment decision; it indicates that 1 unit increase in leverage leads to 0.492

unit decrease in investment. Results are similar with previous studies (e.g., Aviazian et al., 2005; Odit \& Chittoo, 2008; Singhania \& Seth, 2010). The liquidity positively influences firm's investment $(\beta=0.003$; $p$ $<0.01)$. However, the magnitude of this effect is not so strong as compared to other variables of the study. Results confirm to those of Franklin and Mouthsamy (2011).

Profitability also exerts positive effect on firm's investment $(\beta=1.289 ; \mathrm{p}<0.01)$; it shows that profitable firms make more investment in chemical sector as profitability brings more internal funds. The similar findings were given by Odit and Chittoo (2008) and Bao (2010). Cash availability also brings more opportunities for investment, and larger firms make more investment. Singhania and Seth (2010), Jiming et al. (2010) and Jahanzaib and Yameen (2006) reported the same type of results.

\section{CONCLUSION}

This study creates the links of finance theory with empirical analysis of companies in Pakistan. In earliest work by Stutz (1988, 1990), Myers (1977) and McConnell (1995), it was proposed that financial leverage could have either positive or negative effect on firm's investment decision due to overinvestment or underinvestment hypotheses respectively. However, our study supports underinvestment hypothesis that leverage puts negative pressure on financial managers to reduce investment due to agency problem as they do not find personal benefits in such investments. We have found negative effect of financial leverage on investment and confirm to those of previous studies (Aivazian et al., 2005; Jahanzaib \& Naeem,2015; Odit \& Chittoo, 2008). The results contradict with Irrelevance theory, Fisher Separation Theorem and Theory of Investment that consider investment as an independent decision. However, financial markets are not as efficient as they are considered to be in real world.

Liquidity, cash flows, firm size and profitability have positive effect on investment. These factors should also be considered by managers while making investment 
decisions. The firms keep higher level of liquidity in chemical sector for contingency purpose and to avoid technical insolvency problem. Cash flows affect investment decision and considered to be cheaper source of internal financing due to capital market imperfection. It supports Pecking Order Theory. Similarly, larger firms make more investment than smaller firms, and higher level of profitability brings higher level of investment as it results in cheaper funds.

There could be several possible reasons that may be attributed to negative relation between leverage and investment. Firstly, capital markets are not mature in developing countries, so companies rely upon cash flows and profitability for making more investment. There are many problems that need to be solved, like the blocking of financing channels, unclear property rights, insufficient legal system, etc. Secondly, companies may use leverage for making investment in working capital.Thirdly, in the lending decision, banks may usually prefer state owned firms to others. Because of the government guidance, banks may have strong incentive to provide a loan to state owned firms. Lastly, managers may under invest and do not take positive NPV projects when they observe that benefits from such investment would flow out to lenders due to financial leverage.

\section{Policy Implications and Recommendations}

Our findings have determined an important role of capital structure for investment decision. This research study has implications for managers, investors, shareholders and regulatory authorities to consider these findings while making policy decision. Managers should make appropriate use of available funds for the longterm growth and survival. Board of directors should motivate the managers to reduce asset substitution or underinvestment problem by linking their performance to certain incentive. They could also impose penalties for taking wrong investment decision in case of overinvestment hypothesis.

\section{Direction for Future Research}

This research could be extended by taking more industries and variables relating to corporate governance, ownership structure, and other financial variables. The firms could be divided into higher growth and lower growth firms to find out differences in investment patterns. There could be a possibility of non-linear effect of debt on firm's investment, which has not been yet tested in Pakistan. The future research could also be undertaken to find out whether overinvestment or underinvestment theory holds in our corporate sector, and in which industries.

\section{REFERENCES}

Aivazian, V. A., Ge, Y., \& Qiu, J. (2005). The impact of leverage on firm Investment :Canadian evidence. Journal of Corporate Finance ,11(1), 277-291.

Asif, A., Rasool, W., \& Kamal, Y. (2011). Impact of financial leverage on dividend Policy: Empirical evidence from Karachi stock exchangelisted companies. African Journal of Business Management, 5(4), 1312-1324.

Amidu, M. (2007). Determinants of capital structure of banks in Ghana: An empirical approach. Journal of Management, 2(1), 67-79.

Bao, H. (2010). A study on leverage and firm investment: Chinese evidence. Journal of Business, 24-39.

El-Wahid, M. S. M., \& Su'ad Husnan, D. (2011). The impact of financial leverage onprofitability Study of non-ninancial companies listed in Indonesia stock exchange. European Journal of Economics, Finance and Administrative Sciences, 136-147.

Fama, E. F., \& French, K. R. (1988). Taxes financing decisions and firm value. The Journal of Finance, 53(1), 819-844.

Franklin. J.,\&. Mouthsamy, K. (2011). Impact of leverage on firms Investment decision. International Journal of Scientific \& Engineering Research, 1-16.

Guney, Y., Ozkan, A., \& Ozkan, N. (2007). International evidence on the non-linear impact of leverage on corporate cash holdings. Journal of Financial Management, 17(1), 45-60.

Harrris, M., \& Raviv, A. (1990). Capital structure and the informational role of debt. Journal of Finance, 45(2), 321-349.

Harrris, M., and A. Raviv (1991). The theory of capital structure. Journal of Finance, 46(1), 297-335.

Hyde, S. (2007). The response of industry stock returns to market, exchange rate and interest rate risks. Journal of Managerial Finance, 33(9), 693-709.

Jiming, L., Chengqin, S.,\& Zhaohua, W. (2010). The impact of debt financing on firm investment behavior: Evidence from China. International Journal of Digital Content Technology and its Applications, 17-26.

Jahanzaib, K., Naeem, U. (2015). The impact of leverage on firm investment. Research Journal of Recent Sciences, 4(5), 67-70.

Joseph, N. (2002). Modeling the impacts of interest rate and exchange rate changes on UK stock returns. Derivatives Use, Trading and Regulation, 306323.

Ju, N., \& Ou-Yang, H. (2006). Capital structure, debt maturity, and stochastic interest rates. Journal of Business, 79(5), 2470-2502.

Kannadhasan, M. (2014). Does financial leverage 
influence investment decisions? The case of pharmaceutical firms in India. Retrieved from https:/www.researchgate.net/profile/Manoharan Kannadhasan/publication.

Kannadhasan, M., \& Aramvalarthan, S. (2011). Relationships among business strategy, environmental uncertainty and performance of firms operating in Transport equipment industry in India. Journal of Emerging Financial Market, 2(2), 39-50.

Lang, L., Ofek, E., \& Stulz, R. (1996). Leverage, investment, and firm growth. Journal of financial Economics, 40(1), 3-29.

Lawrence, D., Diewert, W. E., \& Fox, K. J.(2004). The Contributions of productivity, price changes and firm size to profitability. Journal of Productivity Analysis, 26(1), 1-13.

Marsh, P. (1982). The choice between equity and debt: An empirical study. Journal of Finance, 37(1), 121-144.

McConnell, J. J. (1995). Equity ownership and the two faces of debt. Journal of Financial Economics, 39(1), 131-157.

McConnell, J. J.\& Servaes, H. (1990) Additional evidence on equity ownership and corporate value, Journal of Financial Economics, 27(2), 595-612.

Modigliani, F., \& Miller, M. (1958). The Cost of capital, corporation finance and the theory of investment. The American Economic Review, 48(3), 261-297.

Modigliani, F., \& Miller, M. (1963). Corporate income taxes and the cost of capital. The American Economic Review, 58(3), 433-444.

Myers, S. C. (1977). Capital Structure. Journal of Economic Perspectives, 15(2), 81-102.

Myers, S. C., \& Majluf, N. S.(1984). Corporate financing and investment decisions when firms have Information and investors do not have. Journal of Financial Economics, 13(2), 187-221.

Myers, S. C., \& Turnbull, S. M. (1977). Capital budgeting and the capital asset pricing model: Good news and bad news. Journal of Finance, 32(2), 321-333.

Odit, M. P., \& Chittoo, H. B.(2008). Does financial leverage influence investment decisions?The case Of Mauritian firms. Journal of Business Case Studies, 4(9), 49-60.

Singhania , M., \& Seth, A. (2010). Financial leverage and investment opportunities in India: An empirical study. International Research Journal of Finance and Economics, 40, 215-226.

Stulz, R. (1990). Managerial discretion and optimal financing policies. Journal of Financial Economics, 26(1), 3-27.

Sajid, M., Tahir, S. H. and Sabir, H. (2015). Does financial leverage influence investment decisions? Empirical evidence from KSE-30 index of Pakistan. Handbook on Economics, Finance and Management Outlooks. 3, 41-46.

Wiwattanakantang, Y. (1999). An Empirical study on the determinants of the capital structure of Thai firms. Pacific-Basin Finance Journal, 7(3), 371-403. 